\title{
Distribution of HBcAg in hepatitis B detected by immunoperoxidase staining with three different preparations of anti-HBc antibodies
}

\author{
S KAKUMU, M ARAO, K YOSHIOKA, Y TSUTSUMI, M INOUE \\ From the Third Department of Internal Medicine, Nagoya University School of Medicine, Nagoya, Japan
}

SUMMARY To evaluate the role of the expression of hepatitis B core antigen (HBcAg) in liver cell damage the immunoperoxidase staining pattern of cryostat liver biopsy specimens from 16 chronic carriers of hepatitis B surface antigen ( $\mathrm{HBsAg}$ ) was investigated using three different kinds of anti$\mathrm{HBc}$ antibodies. Polyclonal antibody prepared from recombinant $\mathrm{HBcAg}$ seemed to be more sensitive in detecting $\mathrm{HBcAg}$ than did monoclonal antibody from the same antigen. The topographical distribution of $\mathrm{HBcAg}$ detected by these two antibodies was similar, showing a close correlation to the histological activity of disease. Furthermore, the predominant localisation of cytoplasmic HBcAg usually reflected an active and severe ongoing hepatitis. On the other hand, monoclonal antibody prepared from purified Dane particles resulted in the prominent cytoplasmic staining for $\mathrm{HBcAg}$ regardless of histological severity of the hepatitis. The quantitative expression and topographical distribution of $\mathrm{HBcAg}$ depended on the type of anti-HBc antibodies used.

Three different antigens have been identified in the sera of persons infected with hepatitis B virus: surface antigen, core antigen, and e antigen. Hepatitis $B$ core antigen $(\mathrm{HBcAg})$ exists on the core of Dane particles, and hepatitis $\mathrm{B}$ e antigen $(\mathrm{HBeAg})$ is a protein separate from the other particulate antigens. The presence of $\mathrm{HBeAg}$ in the serum correlates with $\mathrm{HBcAg}$ as an antigenic marker of Dane particles ${ }^{1}$ and a high reactivity for $\mathrm{HBsAg}$-associated DNA polymerase which is contained in the core of Dane particles. ${ }^{23}$

The presence of $\mathrm{HBcAg}$ in infected liver tissue is usually assumed to indicate ongoing virus replication. $^{4-8}$ Furthermore, $\mathrm{HBcAg}$ has been proposed as a possible immunological target for $T$ cell mediated hepatocyte injury in chronic hepatitis B virus infection in experiments using autologous hepatocytes. ${ }^{9}$ Several investigators have attempted to correlate the distribution of $\mathrm{HBcAg}$ in the hepatocytes with the extent of liver inflammatory activity, but the results remained inconclusive. ${ }^{4-8} \mathrm{HBcAg}$ was principally seen within hepatocyte nuclei. A more recent study showed that cytoplasmic and membrane associated $\mathrm{HBcAg}$ was found to be more widespread

Accepted for publication 6 October 1988 than suspected when an improved immunochemical method was used. ${ }^{10}$ Our previous study also showed that $\mathrm{HBcAg}$ was found mainly in the cytoplasm of hepatocytes in patients with type B chronic liver disease. ${ }^{.1}$

These findings led us to consider that the difference of antibodies used to determine the localisation of $\mathrm{HBcAg}$ might have been responsible for the disparate results. The method used might also be an important factor in influencing the sensitivity of detection. We conducted the present study with three different antibodies to $\mathrm{HBcAg}$ to evaluate the localisation of $\mathrm{HBcAg}$ in livers chronically infected with hepatitis B virus by staining cryostat sections with immunoperoxidase.

\section{Material and methods}

Sixteen patients with chronic hepatitis B virus infection were studied. Ten were seropositive for $\mathrm{HBeAg}$ and five were seropositive for anti-HBe. Histological diagnoses were made according to the criteria of an international group. ${ }^{12}$ Of the 16 cases, 10 had chronic active hepatitis, four had chronic persistent hepatitis, and two had non-specific reactive hepatitis. Details of the patients studied are summarised in table 1 .

Serum $\mathrm{HBsAg}$, anti-HBs, anti-HBc, $\mathrm{HBeAg}$ and 
Table 1 Clinical data and distribution of HBcAg in livers of 16 chronic $\mathrm{HBs} A \mathrm{~g}$ carriers

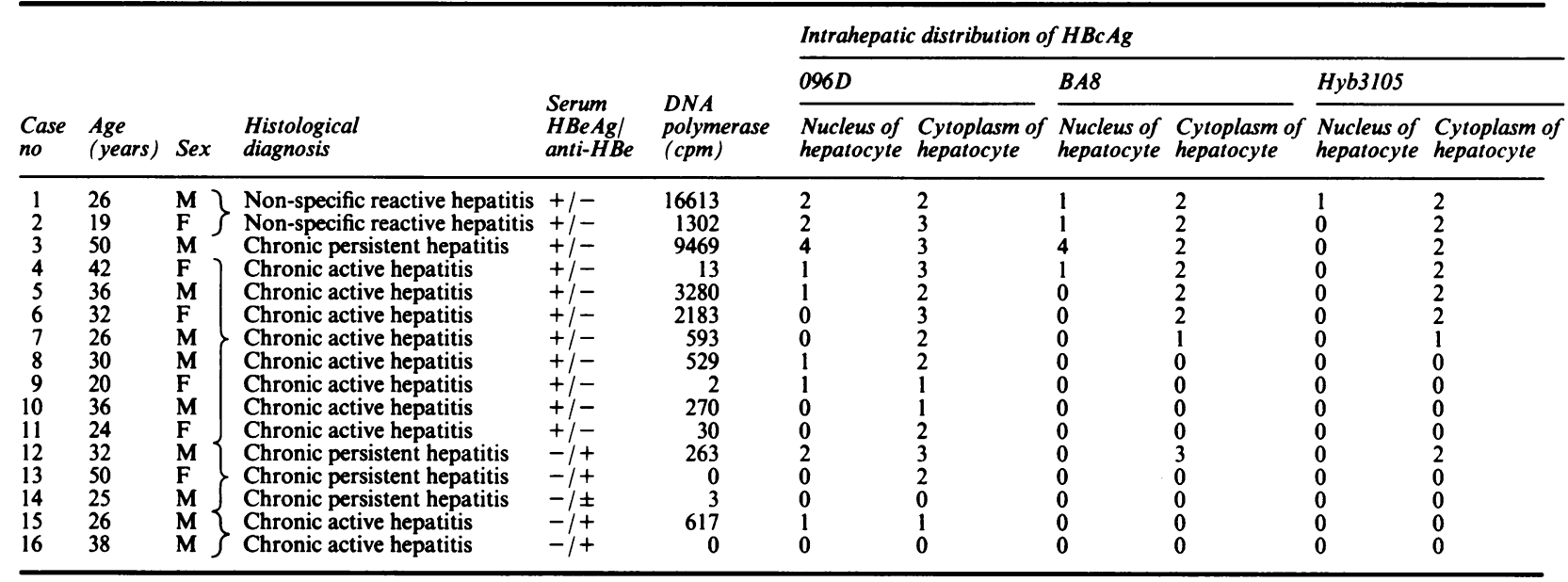

Scale of 0 to 4 corresponding to positivity in $0 \%, 1-10 \%, 11-30 \%, 31-50 \%,>50 \%$ of total hepatocytes examined.

096D = Lot No of polyclonal anti-HBc antibody to recombinant $\mathrm{HBcAg}, \mathrm{BA} 8=$ monoclonal antibody (clone BA8) to recombinant $\mathrm{HBcAg}$, Hyb $3105=$ monoclonal antibody (clone 3105 ) to core of Dane particle.

anti-HBe were assayed by commercially available radioimmunoassay kits (Abbott Laboratories, Chicago, Illinois).

Three kinds of antibodies to $\mathrm{HBcAg}$ were used as first antibody for the immunoperoxidase procedure. First, rabbit polyclonal whole serum to recombinant $\mathrm{HBcAg}$ (Lot No 096D) was purchased from Dako Corporation (Santa Barbara, California) and diluted to $1 / 200$. $\mathrm{HBcAg}$ as immunogen was purified from lysates of Escherichia coli clones containing the viral core DNA, according to the method of Stahl et al. ${ }^{13}$ Second monoclonal antibody (produced by clone BA8) to recombinant $\mathrm{HBcAg}$ (purchased from Biogen SA, Geneva, Switzerland) was kindly provided by Green Cross Corporation (Osaka, Japan) ${ }^{14}$ and used at a concentration of $100 \mu \mathrm{g} / \mathrm{ml}$. Thirdly, monoclonal antibody (produced by cell line 3105 ) to $\mathrm{HBcAg}$, in which core particles were prepared from Dane particles purified from sera of asymptomatic carriers of HBsAg, ${ }^{15}$ was kindly provided by Dr M Imai at Jichi Medical School (Tochigi-Ken, Japan) and used at a concentration of $20 \mu \mathrm{g} / \mathrm{ml}$. All dilutions were done by adding $2 \%$ bovine serum albumin (BSA) to phosphate buffered saline (PBS) to reduce unwanted background staining.

Liver biopsy samples obtained from all patients were divided into two parts. One part was fixed in $10 \%$ formalin for routine histological examination. The other portion was fixed in a periodate-lysine-paraformaldehyde (PLP) solution for immunohistochemistry. ${ }^{16}$ Cryostat consecutive sections $(6 \mu \mathrm{m})$ of the fixed liver samples were pretreated with hydrogen peroxidase and methanol to inactivate endogeneous tissue peroxidase. The sections were incubated with three kinds of monoclonal and polyclonal antibodies to $\mathrm{HBcAg}$ as first antibody at $4^{\circ} \mathrm{C}$ for 24 hours. After washing in PBS they were treated with normal goat serum for 10 minutes and followed by incubation with horseradish-peroxidase-conjugated goat $F\left(\mathrm{ab}^{\prime}\right)_{2}$ antimouse IgG diluted $1 / 80$ or goat anti-rabbit IgG diluted 1/80 (TAGO Corporation, Burlingame, California) (second antibody), which had been absorbed to remove cross reactivity to human serum proteins at $4^{\circ} \mathrm{C}$ for 12 hours. After washing in PBS they were treated with diaminobenzidine solution containing hydrogen peroxidase for 10 minutes, counterstained with methyl green, dehydrated, and mounted. All reagents were previously absorbed against normal human liver. No staining was seen using negative control reagents such as normal mouse or rabbit serum in place of anti-HBc antibodies as the first antibody. There was no staining when polyclonal and monoclonal anti-HBc used here were preincubated with $\mathrm{rHBcAg}{ }^{13}$ or purified core particles. ${ }^{15}$

Each slide was coded and read by two independent observers on a light microscope. The expression of $\mathrm{HBcAg}$ was scored on a 0 to 4 scale corresponding to positivity in $0 \%, 1-10 \%, 11-30 \%, 31-50 \%,>50 \%$ of total hepatocytes examined.

The difference in the number of hepatocytes positive for $\mathrm{HBcAg}$ between two groups of patients was compared using the Wilcoxon rank sum test.

\section{Results}

$\mathrm{HBcAg}$ in liver cells from 16 patients was found in 14 
Table 2 Association between serological patterns (HBeAg/anti-HBe and DNA polymerase) and intrahepatic distribution of $\mathrm{HBCAg}$

\begin{tabular}{|c|c|c|c|c|c|c|c|}
\hline \multirow[b]{3}{*}{ Serum patterns or histological diagnosis } & \multirow{3}{*}{$\begin{array}{l}\text { No of } \\
\text { cases }\end{array}$} & \multicolumn{6}{|c|}{ Intrahepatic distribution of $\mathrm{HBCAg}$ (positive $\mathrm{No}$ ) } \\
\hline & & \multicolumn{2}{|l|}{$096 D$} & \multicolumn{2}{|l|}{$B A 8$} & \multicolumn{2}{|c|}{ Hyb 3105} \\
\hline & & Nucleus & Cytoplasm & Nucleus & Cytoplasm & Nucleus & Cytoplasm \\
\hline $\begin{array}{l}\text { HBeAg Positive } \\
\text { Negative } \\
\text { DNA polymerase Positive } \\
\text { Negative } \\
\text { Non-specific reactive hepatitis } \\
\text { Chronic persistent hepatitis } \\
\text { Chronic active hepatitis }\end{array}$ & $\begin{array}{r}11 \\
5 \\
11 \\
5 \\
2 \\
4 \\
10\end{array}$ & $\begin{array}{l}7 \\
2 \\
7 \\
2 \\
2 \\
2 \\
5\end{array}$ & $\begin{array}{r}11 \\
3 \\
11 \\
3 \\
2 \\
3 \\
9\end{array}$ & $\begin{array}{l}4 \\
0 \\
3 \\
1 \\
2 \\
1 \\
1\end{array}$ & $\begin{array}{l}7 \\
1 \\
7 \\
1 \\
2 \\
2 \\
4\end{array}$ & $\begin{array}{l}2 \\
0 \\
2 \\
0 \\
1 \\
1 \\
0\end{array}$ & $\begin{array}{l}7 \\
1 \\
7 \\
1 \\
2 \\
2 \\
4\end{array}$ \\
\hline
\end{tabular}

096D = Lot No of polyclonal anti-HBc antibody to recombinant $\mathrm{HBcAg}, \mathrm{BA8}=$ monoclonal antibody (clone BA8) to recombinant $\mathrm{HBcAg}$, $\mathrm{Hyb} 3105=$ monoclonal antibody (clone 3105) to core of Dane particle.

subjects by 096D, eight by BA8, and eight by Hyb 3105 anti-HBc antibody, respectively. Of five patients with negative serum DNA-P values, $\mathrm{HBcAg}$ was detected in three by $096 \mathrm{D}$, in one by BA8, and in one by $\mathrm{Hyb}$ 3105 , while of 11 patients with positive serum DNA-P activities, HBcAg was present in all by 096D, seven by BA8, and seven by Hyb 3105 antibody, respectively (table 2).

When 096D was used, $\mathrm{HBcAg}$ was almost equally detected in both the nuclei and cytoplasm in patients with non-specific reactive hepatitis and chronic persistent hepatitis; cytoplasmic expression of $\mathrm{HBcAg}$ was more prominent in patients with chronic active hepatitis (tables 1 and 2). Similar results were obtained for $\mathrm{HBCAg}$ distribution by BA8, although the sensitivity to detect $\mathrm{HBcAg}$ was lower in BA8 than in 096D. On the other hand, Hyb 3105 gave more prominent cytoplasmic staining of $\mathrm{HBcAg}$ even in patients with non-specific reactive hepatitis and chronic persistent hepatitis, and the sensitivity of $\mathrm{Hyb}$ 3105 for detecting $\mathrm{HBcAg}$ was similar to that of BA8.

As shown in the figure, distinct patterns of $\mathrm{HBcAg}$ distribution and different numbers of $\mathrm{HBcAg}$ positive hepatocytes were seen when different anti-HBc antibodies (096D and Hyb 3105) were used for the frozen sections of the liver from an $\mathrm{HBeAg}$ positive patient with chronic persistent hepatitis (case 3).

\section{Discussion}

The results of this study have confirmed previous observations by others that there are various patterns of $\mathrm{HBcAg}$ distribution in the hepatocytes of patients with chronic hepatitis $B$ virus infection. ${ }^{4-10}$ The important finding of this study is that the quantitative expression and topographical distribution of $\mathrm{HBcAg}$ depend on the anti-HBc antibodies used, although they are also closely related to the histological activity and to the antibody status of $\mathrm{HBeAg} /$ anti- $\mathrm{HBe}$ of the patients. 096D and BA8 antibodies are derived from the same immunising antigen, rHBcAg of Biogen SA, Switzerland. ${ }^{13} 096 \mathrm{D}$ is a polyclonal antibody raised in rabbits and BA8 is a monoclonal antibody. These two antibodies gave very similar staining for the topographical distribution of $\mathrm{HBcAg}$, but $096 \mathrm{D}$ was more sensitive in detecting $\mathrm{HBcAg}$ than BA8. This finding suggests that the affinity of these antibodies to the corresponding epitopes may be different; polyclonal antibody could recognise plural antigenic determinants and then react more strongly with the corresponding antigen. The immunising antigen against $\mathrm{Hyb}$ 3105 antibody was core particles which were prepared from Dane particles. ${ }^{15}$ Therefore Hyb 3105 may react with an epitope of $\mathrm{HBcAg}$ which is distinct from the epitope reacted with BA8. Thus when Hyb 3105 was used, cytoplasmic staining for $\mathrm{HBcAg}$ always predominated regardless of histological activity in the liver, unlike the results obtained with 096D or BA8.

Even when studies were performed with the same anti-HBc antibody (Dako corporation) and on the similar category of patients, some investigators noted that $\mathrm{HBcAg}$ was distributed mainly in the nuclei, while others observed prominent expression of cytoplasmic HBcAc. ${ }^{8101718}$ Gowans et al showed that of the two immunofluorescence techniques for detecting $\mathrm{HBcAg}$ in frozen sections, the indirect method was more sensitive than the direct one. ${ }^{10}$ They also indicated that the indirect reaction detected $\mathrm{HBcAg}$ in the cytoplasm of a population of cells previously thought to be negative for $\mathrm{HBcAg}$ and in the cytoplasm of some cells which were thought to contain only nuclear $\mathrm{HBcAg}$. We fixed liver biopsy samples in a PLP solution for immunohistochemistry. Yamada et al reported that PLP fixative effectively preserved the tissue structure and the antigenecity of $\mathrm{HBsAg}$ and $\mathrm{HBcAg} .{ }^{19}$ Our present results were consistent with those of Gowans et al. ${ }^{10}$

The predominant localisation of cytoplasmic 


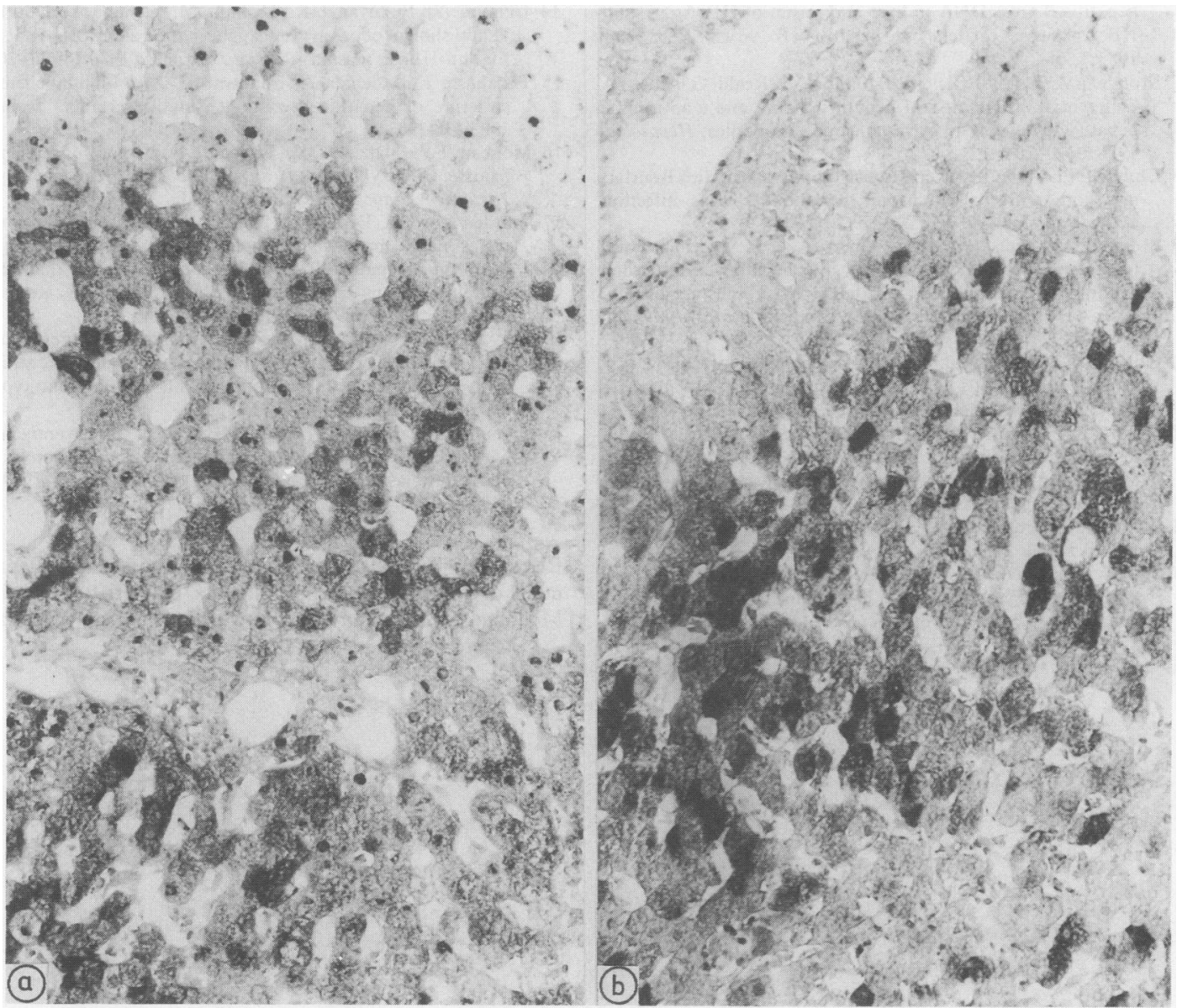

Figure Comparison of same field in two sequential frozen sections from liver (case 3) stained for $\mathrm{HBcAg}$ by immunoperoxidase procedure. (a) $\mathrm{HBcAg}$ was distributed both in the nuclei and cytoplasm of many hepatocytes when polyclonal anti-HBc antibody (096D) prepared from recombinant $\mathrm{HBcAg}$ was used. (b) $\mathrm{HBcAg}$ was detectable in the cytoplasm of many hepatocytes, but nuclear staining was seen only in a few hepatocytes when monoclonal anti-HBc antibody (Hyb 3105) prepared from Dane particles was used.

$\mathrm{HBcAg}$ usually reflects an active and severe ongoing hepatitis. ${ }^{818}$ It remains unclear, however, whether the changes in expression and distribution of $\mathrm{HBcAg}$ in liver are the cause or the effect of the worsening of the chronic liver disease. In any case future studies of the clinical importance of hepatic $\mathrm{HBcAg}$ as an indicator of virus replication and as a possible target for immune cell damage should clearly distinguish nuclear from cytoplasmic sites of HBcAg. A method (including appropriate anti-HBc antibody) capable of detecting low concentrations of cytoplasmic $\mathrm{HBcAg}$ should be used.

\section{References}

1 Takahashi K, Imai M, Tsuda F, Takahashi T, Miyakawa Y,
Mayumi M. Association of Dane particles with e antigen in the serum of asymptomatic carriers of hepatitis B surface antigen. $J$ Immunol 1976;117:102-5.

2 Nordenfeld E, Kjellen L. Dane particles, DNA polymerase, and e-antigen in two different categories of hepatitis B antigen carriers. Intervirology 1975;5:225-32.

3 Imai M, Tachibana K, Moritsugu Y, Miyakawa Y, Mayumi M. Hepatitis B antigen-associated deoxyribonucleic acid polymerase activity and e antigen/anti-e system. Infect Immun 1076;14:631-5.

4 Huang SN, Neurath AR. Immunohistologic demonstration of hepatitis B viral antigens in liver with reference to its significance in liver injury. Lab Invest 1979;40:1-17.

5 Bonino F, Hoyer B, Nelson J, Engle R, Verme G, Gerin J. Hepatitis B virus DNA in the sera of $\mathrm{HBsAg}$ carriers: A marker of active hepatitis B virus replication in the liver. Hepatology 1981;1:386-91.

6 Hadziyannis SJ, Lieberman HM, Karvountzis GG, Shafritz DA. Analysis of liver disease, nuclear $\mathrm{HBcAg}$, viral replication, and 
hepatitis B virus DNA in liver and serum of $\mathrm{HBeAg}$ vs. anti$\mathrm{HBe}$ positive carriers of hepatitis B virus. Hepatology 1983;3:656-62.

7 Mondelli M, Tedder RS, Ferns B, Pontisso P, Realdi G, Alberti A. Differential distribution of hepatitis $B$ core and $e$ antigens in hepatocytes: Analysis by monoclonal antibodies. Hepatology 1986;6:199-204.

8 Chu CM, Liaw YF. Intrahepatic distribution of hepatitis B surface and core antigens in chronic hepatitis $B$ virus infection. Gastroenterology 1987;92:220-5.

9 Mondelli M, Mieli-Vergani G, Alberti A, et al. Specificity of T lymphocyte cytotoxicity to autologous hepatocytes in chronic hepatitis B virus infection: Evidence that $T$ cells are directed against $\mathrm{HBV}$ core antigen expressed on hepatocytes. J Immunol 1982;129:2773-8.

10 Gowans EJ, Burrell CJ. Widespread presence of cytoplasmic $\mathrm{HBcAg}$ in hepatitis B infected liver detected by improved immunochemical methods. J Clin Pathol 1985;38:393-8.

11 Tahara H, Hirofuji H, Kakumu S, Sakamoto N. Intrahepatic distribution of hepatitis B virus (HBV)-associated and HLA class I antigens in patients with chronic liver disease B. Acta Hepatol Jpn 1987;28:1149-56.

12 International group. Acute and chronic hepatitis revisited. Lancet 1977;ii:914-9.

13 Stahl S, MacKay P, Magazin M, Bruce SA, Murray K. Hepatitis B virus core antigen: synthesis in Escherichia coli and application in diagnosis. Proc Natl Acad Sci USA 1982;79:1606-10.
14 Uemura Y, Fukuyama K, Nishida M, Suyama T, Ohori H. Establishment of passive hemagglutination assay (PHA) system for anti-HBc in plasma. Tohoku J Exp Med 1986;149:11-20.

15 Takahashi K, Machida A, Funatsu G, et al. Immunochemical structure of hepatitis B e antigen in the serum. J Immunol 1983;130:2903-7.

16 McLean IW, Nakane PK. Periodate-lysine-paraformaldehyde fixative: A new fixative for immunoelectron microscopy. $J$ Histochem Cytochem 1974;22:1077-83.

17 van den Oord JJ, De Vos R, Desmet VJ. In situ distribution of major histocompatibility complex products and viral antigens in chronic hepatitis B virus infection: Evidence that $\mathrm{HBC}$ containing hepatocytes may express HLA-DR antigens. Hepatology 1986;6:981-9.

18 Yoo JY, Howard R, Waggoner JG, Hoofnagle JH. Peroxidaseanti-peroxidase detection of hepatitis $B$ surface and core antigen in liver biopsy specimens from patients with chronic type B hepatitis. J Med Virol 1987;23:273-81.

19 Yamada G, Nakane PK. Hepatitis B core and surface antigens in liver tissue; Light and electron microscopic localisation by the peroxidase-labelled antibody method. Lab Invest 1979;36: 649-59.

Requests for reprints to: Dr Shinichi Kakumu, Third Department of Internal Medicine, Nagoya University School of Medicine, 65 Tsuruma-cho, Showa-ku, Nagoya 466, Japan. 